\title{
Is intraoperative nerve monitoring useful for surgical training in thyroid surgery?
}

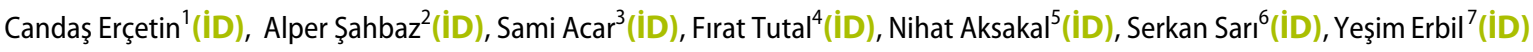 \\ ${ }^{1}$ Department of General Surgery, Health Sciences University, Bağcllar Training and Research Hospital, İstanbul, Turkey \\ ${ }^{2}$ Department of General Surgery, Health Sciences University, Bakırköy Dr. Sadi Konuk Training and Research Hospital, İstanbul, Turkey ${ }^{3}$ \\ Department of General Surgery, Acıbadem Taksim Hospital, İstanbul, Turkey \\ ${ }^{4}$ Department of General Surgery, Kolan International Hospital, İstanbul, Turkey \\ ${ }^{5}$ Department of General Surgery, İstanbul University Istanbul School of Medicine, Istanbul, Turkey \\ ${ }^{6}$ Department of General Surgery, Health Sciences University, İstanbul Training and Research Hospital, İstanbul, Turkey \\ ${ }^{7}$ Department of General Surgery, İstanbul University İstanbul School of Medicine, İstanbul, Turkey
}

\section{ABSTRACT}

Objective: Parathyroid glands and recurrent laryngeal nerves (RLNs) are at risk during thyroid surgery. However, the identification of the nerves has reduced these risks. Intraoperative nerve monitoring (IONM) during thyroid surgery has gained widespread acceptance as an aid to the gold standard of visually identifying the RLN. The aim of the present study was to evaluate the effect of the identification of the RLN during thyroidectomy by using IONM.

Material and Methods: Seven hundred forty-eight patients were included in our prospectively designed study. Of these 748 patients, 1496 nerves at risk were studied. Group 1 consisted of 736 nerves that were identified using IONM, whereas Group 2 consisted of 760 visually identified nerves.

Results: In the non-IONM group, the rate of temporary nerve palsy was lower in patients operated by experienced surgeons than in patients operated by residents $(p=0.001)$. In the IONM group, RLN injury rates were similar between experienced surgeons and residents.

Conclusion: In spite of the fact that the duration of the operation was lower with IONM, the abbreviated duration may not appear to have clinical significance. The main advantage is for less experienced surgeons. IONM significantly decreases RLN palsy rates of the surgeons with limited experience in thyroid surgery.

Keywords: Thyroidectomy, nerve injury, nerve monitoring

Cite this article as: Erçetin C, Şahbaz A, Acar S, Tutal F, Aksakal N, Sarı S, Erbil Y. Is intraoperative nerve monitoring useful for surgical training in thyroid surgery? Turk J Surg 2019; 35 (4): 259-264.

\section{Corresponding Author}

Candaş Erçetin

E-mail: ercetin@istanbul.edu.tr

Received: 20.08 .2018

Accepted: 24.10 .2018

Available Online Date: 20.11.2018

O Copyright 2019 by Turkish Surgical Society Available online at www.turkjsurg.com

DOI: $10.5578 /$ turkjsurg.4281

\section{INTRODUCTION}

Thyroidectomy is performed very frequently in regions with iodine deficiency. The most serious complications of thyroidectomy are recurrent laryngeal nerve (RLN) palsy and hypoparathyroidism, which can considerably worsen the patients' quality of life. In spite of the fact that the rate of nerve paralysis is small, when it happens, it may be life-long in capacity $(1,2)$. The incidence of nerve paralysis is reported to be 0\%-14\% (1-4). Conditions, such as retrosternal goiter, redo surgeries, or surgeries for malignant thyroid disorders, put the nerves at highest risks, and even experienced surgeons may accidentally damage the recurrent nerve, resulting in nerve paralysis in approximately $1 \%-2 \%$. Since the early 1930's, routine visualization of RLN rather than avoiding it has become the standard of care (5-7).

Intraoperative nerve monitoring (IONM) during thyroid surgery has gained widespread acceptance as an aid to the gold standard of visually identifying the RLN (8-10). Different techniques to monitor the nerve include palpation of the cricothyroid muscle while stimulating the nerve; observation of the glottis for vocal cord movement while stimulating the recurrent nerve, which can be performed by either laryngoscopy or fiberoptic nasopharyngoscopy; monitoring the pressure of the glottis on the endotracheal tube and finally, through surface electrodes placed on the endotracheal tube, which are in contact with the vocal cords (8,9,11-14). Currently, the most common type of IONM is made by an endotracheal tube with electrodes secured on its wall, and those electrodes record the activities of the vocal cords as stimulated. 
Many studies have shown that routine intraoperative RLN monitoring decreases permanent paralysis rates (12,15-18). Nevertheless, its role in foreseeing postoperative nerve function and decreasing RLN injury is an ongoing debate (19-22). The aim of the present study was to assess the effect of intraoperative RLN identification by using IONM during thyroidectomy.

\section{MATERIAL and METHODS}

\section{Patients}

This was a prospectively designed study. Eight hundred fifteen consecutive patients with benign euthyroid thyroid disorders (multinodular goiter) (fine needle aspiration biopsy with suspicion of malignancy, aesthetic concerns, and pressure symptoms) who underwent thyroidectomy at the Department of General Surgery, Istanbul University, Istanbul Medical Faculty between April 2008 and April 2016 were intended to be included into the study.

Exclusion criteria were vocal cord dysfunction on preoperative evaluation, monitoring malfunction, and patient's refusal to par- ticipate in the study. Sixty-seven patients were excluded from the study, with 36 patients for vocal cord paralysis, 11 patients for signal loss, and 20 patients refused to participate in the study. Overall, 748 patients and 1496 nerves at risk were included (Figure 1).

Patients were randomized to have RLNs recognized by visualization or neuronal monitoring throughout the surgery. Randomization of the cases was provided by the resident not working in the study using coins (heads or tails method). Group $1(n=736)$ consisted of nerves, which were recognized with IONM, whereas Group 2 ( $n=760$ ) without IONM. Both groups were further divided into subgroups A and B. Groups 1 A and 2A consisted of patients whose surgeries were performed by a qualified endocrine surgeon ( $n=3)$, and groups $1 B$ and $2 B$ consisted of patients who were operated by $4^{\text {th }}$ year residents $(n=4)$. Ethics committee approval was received for this study from the institutional Ethics Committee of Istanbul University, Istanbul Medical Faculty (762/2007). Informed consent was obtained from all patients.

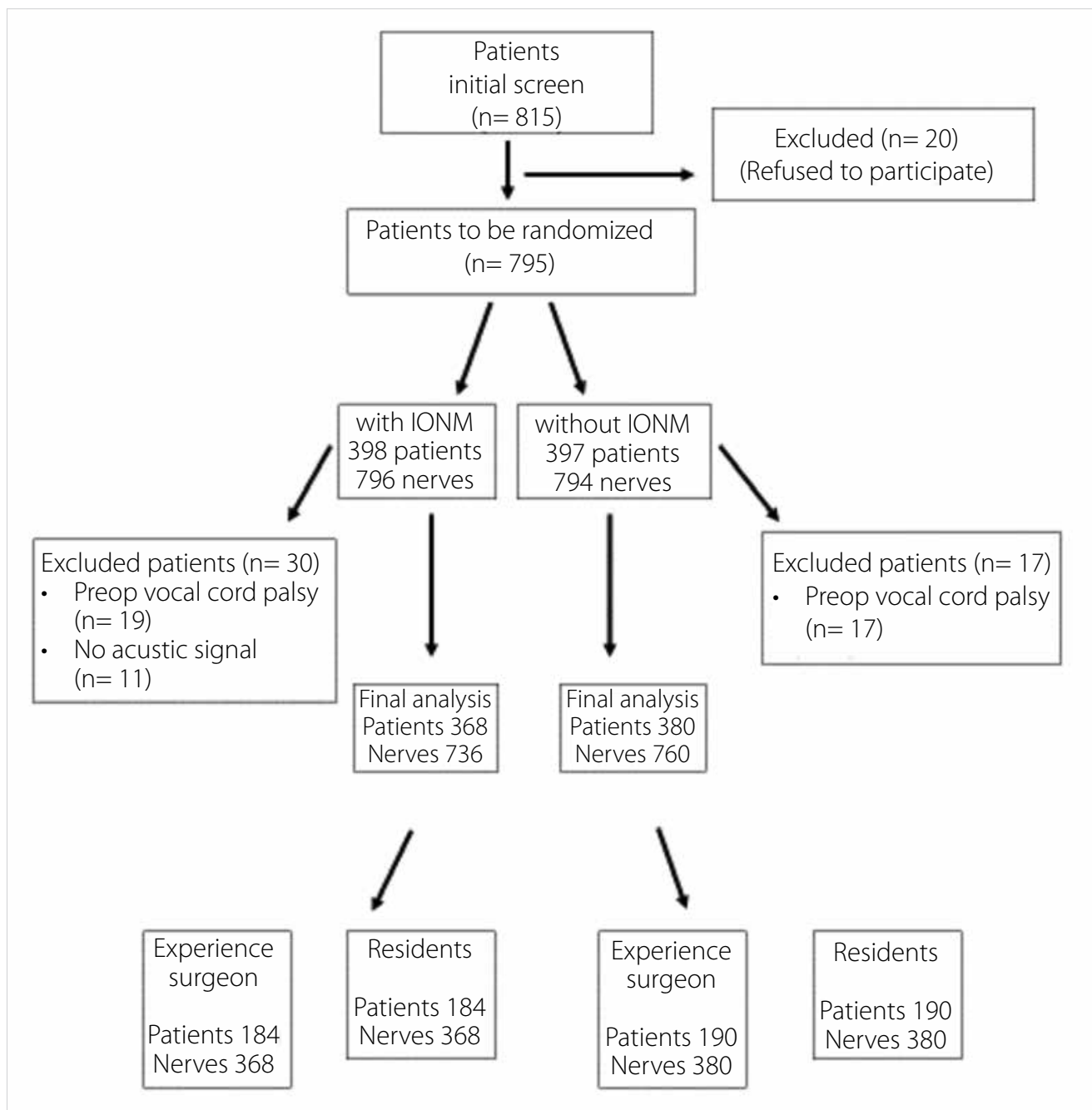

Figure 1. Flowchart of enrolled and randomized patients. IONM: Intraoperative nerve monitoring. 


\section{Technique}

An experienced endocrine surgeon performed thyroidectomies in groups $1 \mathrm{~A}$ and $2 \mathrm{~A}$, and $4^{\text {th }}$ year residents performed surgeries in groups $1 \mathrm{~B}$ and $2 \mathrm{~B}$.

The patient was in supine position under general anesthesia with the neck extended. Following a low collar incision, the superior and inferior subplatysmal flaps were prepared. After the strap muscles were separated and lateralized, the thyroid lobe was freed from its investing fascia and retracted medially. When present, the middle thyroid vein was sealed and cut. The superior thyroid artery and vein were ligated close to the thyroid tissue. The tracheoesophageal groove was prepared and dissected to identify the recurrent nerve. When found, the RLN was delicately freed from the adjacent tissues. As soon as the RLN and parathyroid glands were secured, the ligament of Berry was divided, and the thyroid lobe was detached from its attachments to the trachea.

No neuromuscular blocking agents were utilized during intubation in the IONM group. Endotracheal tube monitoring systems (Medtronic; Nerve Integrity Monitor (NIM), Jacksonville, FL, USA) were used to screen the thyroarytenoid muscles for electromyographic (EMG) activity. Intermittent nerve monitoring was used. The stimulation current was set at $1.5 \mathrm{~mA}$, and a disposable probe was used. First, an EMG signal from the vagus nerve was aimed. Dissection of the RLN was started after the EMG signal was obtained from the vagus nerve, which confirmed the accuracy of the tube placement. The event threshold was set at 100 $\mathrm{mV}$. Then signal from the RLN was obtained in the tracheoesophageal groove, which was totally dissected from the ligament of Berry. If a signal loss occurred at a level of $2 \mathrm{~mA}$, equipment failure was assumed. After hemostasis was performed and the operative field was free of any fluids, the final test of the vagus was performed. Duration of the operation was measured from skin preparation until the end of wound closure.

Both pre- and postoperative laryngoscopic examinations of the patients were performed by an otolaryngologist to assess vocal cord functions. If vocal cord palsy occured, presented with dysphonia, laryngoscopic examinations were repeated on post- operative months 1 and 6 . If clinical dysphonia and dysfunction of the vocal cords lasted > 12 months, it was considered as persistent nerve palsy.

Data regarding age, sex, body mass index (BMI), weight of the resected thyroid tissue, duration of the operation, and postoperative complications (RLN paralysis and hypoparathyroidism) were recorded.

\section{Statistical Analysis}

Statistical analysis was made using the Statistical Packages for the Social Sciences (SPSS) version 21.0 for Windows (IBM Corp.; Armonk, NY, USA). Results were expressed as mean \pm SD. Chisquare test, Wilcoxon signed-rank test, and logistic regression analysis were used for the comparison of data. A p value $<0.05$ was considered as statistically significant.

\section{RESULTS}

\section{Patients}

Male/female ratio, BMI, mean age, mean duration of operation, and mean weight of the thyroid gland were 130/665, $27.4 \pm 3$ $\mathrm{kg} / \mathrm{m}^{2}, 47.8 \pm 13$ years, $83.9 \pm 36 \mathrm{~min}$, and $71.2 \pm 38 \mathrm{~g}$, respectively. There was no operative mortality. Transient vocal cord palsy rate was $2.6 \%$ (20 patients), and temporary hypoparathyroidism rate was $4.4 \%$ (33 patients). There were no persistent vocal cord paralysis and hypoparathyroidism in our series.

\section{Assessment of Patients According to the Presence or Absence of IONM}

Age, gender, and BMI were similar in both groups. There was also no difference between postoperative complication rates and resected weight of the thyroid gland ( $p>0.05$ ) (Table 1).

Mean duration of the operation was significantly longer in Group $2(83.1 \pm 28 \mathrm{~min})$ than in Group $1(69.7 \pm 31 \mathrm{~min})(\mathrm{p}=$ 0.001 ). Duration of operation of surgeries performed by experienced surgeons $(63.7 \pm 27 \mathrm{~min}$ ) was significantly lower than that of surgeries performed by residents $(89.3 \pm 18 \mathrm{~min})(p=0.001)$.

In the non-IONM group, the rate of transient vocal cord palsy was significantly lower in patients who were operated by ex-

Table 1. Comparison of patient demographics in the groups

\begin{tabular}{|c|c|c|c|}
\hline Parameters & $\begin{array}{c}\text { Group } 1(n=398) \\
\text { with IONM }\end{array}$ & $\begin{array}{c}\text { Group } 2(n=397) \\
\text { without IONM }\end{array}$ & $\mathrm{p}$ \\
\hline Age (year) & $47.2 \pm 14$ & $48.3 \pm 12$ & NS \\
\hline Female/Male ratio & $330 / 68$ & $335 / 62$ & NS \\
\hline BMI $\left(\mathrm{kg} / \mathrm{m}^{2}\right)$ & $27.1 \pm 3$ & $27.6 \pm 3$ & NS \\
\hline Thyroid gland weight (g) & $72.6 \pm 41$ & $69.8 \pm 37$ & NS \\
\hline $\begin{array}{l}\text { Complications ( } \mathrm{n}) \\
\text { - } \quad \text { Nerve palsy } \\
\text { - } \quad \text { Hypoparathyroidism }\end{array}$ & $\begin{array}{c}9 \\
17\end{array}$ & $\begin{array}{l}11 \\
16\end{array}$ & NS \\
\hline
\end{tabular}


Table 2. Evaluation of the patients according to the experience level of the surgeon

\begin{tabular}{|c|c|c|c|c|c|}
\hline & & RLN injury & $\mathrm{p}$ & Hypocalcemia & p \\
\hline \multirow[t]{2}{*}{ With IONM $(n=368)$} & Experienced surgeon $(n=184)$ & 4 & \multirow[t]{2}{*}{ NS } & 8 & \multirow[t]{2}{*}{ NS } \\
\hline & Resident surgeon ( $n=184$ ) & 5 & & 9 & \\
\hline \multirow[t]{2}{*}{ Without IONM ( $n=380)$} & Experienced surgeon $(n=190)$ & 3 & \multirow[t]{2}{*}{0.001} & 7 & \multirow[t]{2}{*}{ NS } \\
\hline & Resident surgeon ( $n=190)$ & 8 & & 9 & \\
\hline
\end{tabular}

perienced surgeons than in patients who were operated by residents $(p=0.001)$. In the IONM group, RLN injury rates were similar between experienced surgeons and residents. Transient hypoparathyroidism rates were similar between experienced surgeons and residents in both IONM and non-IONM groups (Table 2).

\section{DISCUSSION}

Nerve palsy and hypoparathyroidism are the most common surgical complications of thyroidectomy. There are many factors affecting the risk of possible nerve injury. Amount of resection, nature of thyroid disease, such as Graves' disease, retrosternal goiter, and malignant diseases, and surgeon experience are among them (1-3). Experienced surgeons also report RLN injury and paralysis in approximately $1 \%-2 \%$ of cases $(1-4,8)$. Paralysis may be caused by too much skeletonization of the nerve, disruption of anatomic integrity, thermal injury, excessive traction of the nerve causing axonal injury, hematoma due to bleeding, edema, and forced intubation. The rates of nerve injury have declined over the last couple of decades owing to nerve identification during operation. Currently, this is the most applied approach by endocrine surgeons $(1-4,8,9)$.

Between 1882 and 1898, Theodor Kocher decreased his operative mortality down to $0.18 \%$, which was as high as $14.8 \%$ before. He even managed to decrease his recurrent nerve injury rates to the levels of today's surgeons with his meticulous dissection technique (23). In 1938, Lahey dissected and visualized the RLN in practically every case he operated on. He reported that careful dissection and visualization of the RLN reduced the amount of injuries (24).

In the literature, nerve palsy rates vary from $<1 \%$ to $20 \%$ despite meticulous dissection techniques (1-3). In some operations, identification of the nerve can be challenging. Redo surgeries, surgery for malignant diseases, anatomical variations, such as non-recurrent nerve, large retrosternal goiters, and inflammation, or radiation history may cause difficulties in the identification of the nerve (1-4).

Identification of the RLN and monitoring its functions during surgery has been made possible through various medical devices developed during the last 20 years (9). Several methods, such as cricoarytenoid muscle palpation while stimulating the nerve, direct or fiber optic laryngoscopy observation of the vocal cords, or vocal cord electrodes, have been described (12-14). However, the most commonly used method among all is the NIM $(17,18)$. In the NIM system, vocal cord electrodes are fixed on the endotracheal tube itself. Thus, there is no need for specific skills or surgical experience; on the other hand, there is a need for skilled anesthesiologist to place the electrodes correctly in regard with the vocal cords $(9,11,17,18)$.

There is recent evidence in the literature stating that neuromonitoring can help dissection and visualization of the RLN $(11,12,15-19)$. However, it is still debatable how effectively NIM can reduce RLN injury rates and predict postoperative nerve function (20-22). In a multicentric large study (16.448 patients with 29.998 nerves at risk), Dralle et al. (11) have revealed no significant difference between visual identification of the nerve and visualization with RLN neuromonitoring. Nonetheless, when the subgroups were evaluated in detail, it revealed a significant decrease in the incidence of permanent RLN palsy in low-volume surgeons who use IONM (11). In addition, being able to identify the nerve before visualization may cause a significant reduction in transient RLN palsy rates (6).

Some researchers have shown that neuromonitoring can be helpful in resident training by means of anatomical identification of the nerve (12-16). In our series, there was a clear benefit of RLN monitoring in surgeries performed by residents. In the non-IONM group, there was a statistically significant difference in RLN palsy rates between residents and experienced surgeons $(p=0.001)$, but in the IONM group, the rates were similar. The RLN palsy rates decreased to the levels comparable with experienced endocrine surgeons when neuromonitoring is used by residents. There was no difference between hypoparathyroidism rates in both groups.

Similar results were also presented by Alesina et al. (25) who analyzed 1116 thyroid procedures performed by residents in their center in the years 2005-2012. In the first group, operations without neuromonitoring were performed by residents assisted by an experienced surgeon, and the percentage of transient RLN injuries was 2.6\%. In the second group, procedures with neuromonitoring were performed by residents assisted by specialists with limited experience in thyroid surgery, and the 
percentage of transient RLN injuries was $2.7 \%$. They concluded that although neuromonitoring could not replace standard RLN identification, yet in the case of surgeons with limited experience in thyroid surgery, it allowed for achieving results that were comparable to the results obtained by more experienced surgeons.

The major disadvantage of this system is that it is very costly. It is clearly more expensive than the conventional technique. In addition, in our study, duration of the operation is significantly lower with IONM, but this shortening might not have great clinical impact.

The limitation in our study is, that the operations performed by four resident and three experienced surgeons. Therefore, oneto-one matching could not be performed.

\section{CONCLUSION}

As most surgeons try to protect the nerves during surgery, we do not think that IONM is an alternative to visual nerve identification, but it may find itself a role as an adjunct to visual identification. Although it may seem to reduce the duration of operation in our series, the major benefit is for less experienced surgeons. IONM significantly decreases RLN palsy rates of surgeons with limited experience in thyroid surgery.

Ethics Committee Approval: Ethics committee approval was received for this study from the institutional Ethics Committee of İstanbul University, İstanbul Medical Faculty (762/2007).

Informed Consent: Written informed consent was obtained from patients who participated in this study.

Peer-review: Externally peer-reviewed.

Author Contributions: Concept - C.E., Y.E.; Design - C.E., Y.E., N.A.; Supervision - A.S., S.A., S.S.; Resource - C.E., F.T., S.A.; Materials - C.E., N.A., S.A.; Data Collection and/or Processing - C.E., N.A., S.S.; Analysis and/or Interpretation - C.E., A.Ş., Y.E.; Literature Search - S.A., F.T., A.S.; Writing Manuscript - C.E., A.S., Y.E.; Critical Reviews - F.T., N.A., S.S.

Conflict of Interest: The authors have no conflicts of interest to declare.

Financial Disclosure: The authors have no conflicts of interest to declare.

\section{REFERENCES}

1. Bergamaschi R, Becouarn G, Ronceray J, Arnaud JP. Morbidity of thyroid surgery. Am J Surg 1998;176:71-5. [CrossRef]

2. Sturniolo G, D'Alia C, Tonante A, Gagliano E, Taranto F, Lo Schiavo MG. The recurrent laryngeal nerve related to thyroid surgery. Am J Surg 1999;177:485-8. [CrossRef]

3. Thomusch O, Machens A, Sekulla C, Ukkat J, Lippert H, Gastinger I, et al. Multivariate analysis of risk factors for postoperative complications in benign goiter surgery: prospective multicenter study in Germany. World J Surg 2000;24:1335-41. [CrossRef]

4. Hermann M, Alk G, Roka R, Glaser K, Freissmuth M. Laryngeal recurrent nerve injury in surgery for benign thyroid diseases: effect of nerve dissection and impact of individual surgeon in more than 27,000 nerves at risk. Ann Surg 2002;235:261-8. [CrossRef]
5. Jatzko GR, Lisborg PH, Muller MG, Wette VM. Recurrent nerve palsy after thyroid operations: principal nerve identification and a literature review. Surgery 1994;115:139-44. [CrossRef]

6. Barczynski M, Konturek A, Cichon S. Randomized clinical trial of visualization versus neuromonitoring of recurrent laryngeal nerves during thyroidectomy. Br J Surg 2009;96:240-6. [CrossRef]

7. Calo PG, Pisano G, Medas F, Tatti A, Pittau MR, Demontis R, et al. Intraoperative recurrent laryngeal nerve monitoring in thyroid surgery: is it really useful? Clin Ter 2013;164:e193-8. [CrossRef]

8. Erbil Y, Barbaros U, Issever H, Borucu I, Salmaslioglu A, Mete O, et al. Predictive factors for recurrent laryngeal nerve palsy and hypoparathyroidism after thyroid surgery. Clin Otolaryngol 2007;32:32-7. [CrossRef]

9. Angelos P. Recurrent laryngeal nerve monitoring: state of the art, ethical and legal issues. Surg Clin North Am 2009;89:1157-69. [CrossRef]

10. LiuXL, Wu CW, Zhao YS, Wang T, Chen P, Xin JW, et al. Exclusive real-time monitoring during recurrent laryngeal nerve dissection in conventional monitored thyroidectomy. Kaohsiung J Med Sci 2016;32:13541. [CrossRef]

11. Dralle H, Sekulla C, Haerting J, Timmermann W, Neumann HJ, KruseE, et al. Risk factors of paralysis and functional outcome after recurrent laryngeal nerve monitoring in thyroid surgery. Surgery 2004;136:131022. [CrossRef]

12. James AG, Crocker S, Woltering E, Ferrara J, Farrar W. A simple method for identifying and testing the recurrent laryngeal nerve. Surg Gynecol Obstet 1985;161:185-6. [CrossRef]

13. Randolph GW, Kobler JB, Wilkins J. Recurrent laryngeal nerve identification and assessment during thyroid surgery: laryngeal palpation. World J Surg 2004;28:755-60. [CrossRef]

14. Djohan RS, Rodriguez HE, Connolly MM, Childers SJ, Braverman B, Podbielski FJ. Intraoperative monitoring of recurrent laryngeal nerve function. Am Surg 2000;66:595-7. [CrossRef]

15. Hermann M, Hellebart C, Freissmuth M. Neuromonitoring in thyroid surgery: prospective evaluation of intraoperative electrophysiological responses for the prediction of recurrent laryngeal nerve injury. Ann Surg 2004;240:9-17. [CrossRef]

16. Snyder SK, Hendricks JC. Intraoperative neurophysiology testing of the recurrent laryngeal nerve: plaudits and pitfalls. Surgery 2005;138:1183-92. [CrossRef]

17. Brauckhoff M, Gimm O, Thanh PN, Brauckhoff K, Ukkat J, Thomusch $O$, et al. First experiences in intraoperative neurostimulation of the recurrent laryngeal nerve during thyroid surgery of children and adolescents. J Pediatr Surg 2002;37:1414-8. [CrossRef]

18. Thomusch O, Sekulla C, Machens A, Neumann HJ, Timmermann W, Dralle $\mathrm{H}$. Validity of intra-operative neuromonitoring signals in thyro-id surgery. Langenbecks Arch Surg 2004;389:499-503. [CrossRef]

19. Dralle H, Sekulla C, Lorenz K, Brauckhoff M, Machens A; German IONM Study Group. Intraoperative monitoring of the recurrent laryngeal nerve in thyroid surgery. World J Surg 2008;32:1358-66. [CrossRef]

20. Chan WF, Lang BH, LO CY. The role of intraoperative neuromonitoring of recurrent laryngeal nerve during thyroidectomy: a comparative study on 1000 nerves at risk. Surgery 2006;140:866-72. [CrossRef]

21. Shindo M, Chheda NN. Incidence of vocal cord paralysis with and without recurrent laryngeal nerve monitoring during thyroidectomy. Arch Otolaryngol Head Neck Surg 2007;133:481-5. [CrossRef]

22. Loch-Wilkinson TJ, Stalberg PL, Sidhu SB, Sywak MS, Wilkinson JF, Delbridge LW. Nerve stimulation in thyroid surgery: is it really useful? ANZ J Surg 2007;77:377-80. [CrossRef] 
23. Giddings AE. The history of Thyroidectomy. J R Soc Med 1998;91:3-6. [CrossRef]

24. Lahey FH. Routine dissection and demonstration of the recurrent laryngeal nerve in subtotal thyroidectomy. Surg Gynecol Obstet 1938;66:775-7. [CrossRef]
25. Alesina PF, Hinrichs J, Meier B, Cho EY, Bolli M, Walz MK. Intraoperative neuromonitoring for surgical training in thyroid surgery: its routine use allows a safe operation instead of lack of experienced mentoring. World J Surg 2014;38:592-8. [CrossRef]

\title{
ORIJINAL ÇALIŞMA-ÖZET
}

Turk J Surg 2019; 35 (4): 259-264

\section{Tiroid cerrahisinde intraoperatif sinir monitörizasyonu cerrahi eğitiminde yararlı mı?}

\author{
Candaş Erçetin ${ }^{1}$, Alper Şahbaz ${ }^{2}$, Sami Acar ${ }^{3}$, Frrat Tutal $^{4}$, Nihat Aksakal ${ }^{5}$, Serkan Sarı ${ }^{6}$, Yeşim Erbil $^{7}$ \\ ${ }^{1}$ Sağlık Bilimleri Üniversitesi Bağcılar Eğitim ve Araştırma Hastanesi, Genel Cerrahi Kliniği, İstanbul, Türkiye \\ ${ }^{2}$ Sağlık Bilimleri Üniversitesi Bakırköy Dr. Sadi Konuk Eğitim ve Araştırma Hastanesi, Genel Cerrahi Kliniği, İstanbul, Türkiye \\ ${ }^{3}$ Acıbadem Taksim Hastanesi, Genel Cerrahi Bölümü, İstanbul, Türkiye \\ ${ }^{4}$ Kolan International Hospital, Genel Cerrahi Bölümü, İstanbul, Türkiye \\ ${ }^{5}$ Istanbul Üniversitesi İstanbul Tıp Fakültesi, Genel Cerrahi Anabilim Dalı, İstanbul, Türkiye \\ ${ }^{6}$ Sağ ık Bilimleri Üniversitesi İstanbul Eğitim ve Araştırma Hastanesi, Genel Cerrahi Kliniği, İstanbul, Türkiye \\ ${ }^{7}$ Istanbul Üniversitesi İstanbul Tıp Fakültesi, Genel Cerrahi Anabilim Dalı, İstanbul, Türkiye
}

\section{ÖZET}

Giriş ve Amaç: Paratiroid bezler ve rekürren laringeal sinirler (RLS) tiroid cerrahisi sırasında risk altındadır. Ancak sinirlerin tanımlanması bu riskleri azaltmaktadır. Tiroid cerrahisi sırasında intraoperatif sinir monitörizasyonu (IOSM) kullanımı, RLS'nin görsel olarak tanımlanmasının altın standardına bir yardımcı olarak yaygın olarak kabul görmektedir. Bu nedenle, bu prospektif çalışma ile tiroidektomi sırasında RLS tanımlamasında iOSM kullanımının etkisini değerlendirmeyi amaçladık.

Gereç ve Yöntem: Yedi yüz kırk sekiz hasta bu prospektif çalışmaya dahil edildi. Bu 748 hastanın risk altındaki 1496 siniri incelemeye alındı. 736 sinirin olduğu grup 1'de sinirler IOSM ile tanımlanırken, 760 sinirin olduğu grup 2'de sinir görsel olarak tanımlandı.

Bulgular: IOSM kullanılmayan gruptaki hastalarda, geçici sinir felci oranı deneyimli cerrahlar tarafından ameliyat edilenlerde kıdemli asistanlara göre daha düşük olarak saptandı $(\mathrm{p}=0.001)$. IOSM kullanılan grupta ise RLS yaralanma oranları deneyimli cerrahlar ve kıdemli asistanlar arasında benzerdi.

Sonuç: Ameliyat süresinin IOSM kullanılan grupta daha düşük olduğu gerçeğine rağmen, kısalmış olan ameliyat süresi klinik bir öneme sahip görünmeyebilir. Asıl avantaj, daha az deneyimli cerrahlar içindir. Tiroid cerrahisinde kısıtı deneyime sahip olan cerrahlarda, IOSM kullanımı RLS felç oranlarını önemli ölçüde azaltmaktadır.

Anahtar Kelimeler: Tiroidektomi, sinir yaralanması, sinir monitörizasyonu

Doi: $10.5578 /$ turkjsurg.4281 